\title{
PENGETAHUAN TENTANG KUNJUNGAN NIFAS DI RUMAH SAKIT ISLAM SULTAN AGUNG SEMARANG
}

\author{
KNOWLEDGE ABOUT POSTPARTUM EXAMINATION AT ISLAMIC \\ HOSPITAL OF SULTAN AGUNG SEMARANG
}

\author{
Indri Astuti Purwanti ${ }^{1}$, Lia Mulyanti², Novita Nining Anggraini ${ }^{2}$ \\ ${ }^{1}$ Program Studi S1 Kesehatan Masyarakat, Fakultas Kesehatan Masyarakat \\ Universitas Muhammadiyah Semarang \\ ${ }^{2}$ Program Studi DIII Kebidanan, Fakultas Ilmu Keperawatan dan \\ Kesehatan, Universitas Muhammadiyah Semarang \\ Email: ia_purwanti@unimus.ac.id
}

\begin{abstract}
ABSTRAK
Provinsi Jawa Tengah merupakan salah satu wilayah yang menyumbang angka kematian ibu terbesar di Indonesia. Proporsi kasus kematian ibu terbanyak terjadi pada masa nifas dan berlokasi di rumah sakit. Diantara kabupaten/kota di Jawa Tengah, Kota Semarang memiliki cakupan kunjungan nifas terendah dan mempuyai jumlah rumah sakit terbanyak tetapi angka kematiannya termasuk tertinggi. Salah satu dugaan penyebab kematian ibu adalah kurangnya informasi sedangkan di Rumah Sakit Islam Sultan Agung Semarang setiap ibu nifas diberi buku tuntunan tentang masa nifas. Tujuan penelitian ini adalah mengetahui pengetahuan tentang kunjungan nifas di Rumah Sakit Islam Sutan Agung Semarang. Jenis penelitian ini adalah explanatory research. Responden penelitian ini adalah ibu nifas yang dirawat inap sebanyak 30 orang. Tehnik sampling menggunakan metode total sampling. Instrumen penelitian ini berupa kuesioner tentang kunjungan nifas berjumlah 20 pertanyaan yang diuji validitas dengan judgement expert. Pengambilan data dilakukan dengan cara survey. Pengolahan data dilakukan dengan nilai minimum, nilai maksimum, rerata dan distribusi frekuensi. Skor pengetahuan responden terendah adalah 2, tertinggi adalah 14, rerata adalah 5,33. Berdasarkan hal tersebut, pengetahuan responden dikategorikan baik jika skor 6 atau lebih dan dikategorikan kurag jika skor di bawah 6. Distribusi frekuensi responden menunjukkan bahwa pengetahuan responden kategori baik sebesar 33,3\% sedangkan kategori kurang sebesar 66,7\%. Sebagian besar responden mempunyai pengetahuan tentang kunjungan nifas dalam kategori kurang.
\end{abstract}

Kata kunci: pengetahuan, ibu nifas, kunjungan nifas, rumah sakit

ABSTRACT

Central Java Province is one of the regions that contribute to the largest maternal mortality rate in Indonesia. The highest proportion of maternal mortality cases occurred after childbirth and was located in the hospital. Among regencies / cities in Central Java, Semarang City has the lowest coverage of postpartum visits and has the highest number of hospitals but the mortality rate is the highest. One of the alleged causes of maternal death is a lack of information while in Islamic Hospital of Sultan Agung Semarang, every postpartum mother is given a guide book about childbirth. The purpose of this study was to find out the knowledge of postpartum visits at Islamic Hospital of Sultan Agung Semarang. This type of research is explanatory research. Respondents of this study were 30 postpartum mothers who were hospitalized. The instrument of this research was a questionnaire about postpartum visits totaling 20 questions that were tested for validity by judgement expert. Data were collected by means of surveys. Data processing is carried out with minimum values, maximum values, mean and frequency distribution. The lowest respondent's knowledge score is 2, the highest is 14, the average is 5.33. Based on this, the respondent's knowledge is categorized as good if the score is 6 or more and categorized as kurag if the score is below 6. The frequency distribution of respondents shows that the respondent's knowledge is good in the category of 33.3\% while the less category is $66.7 \%$. Most respondents in the category lack knowledge about postpartum visits.

Keywords: knowledge, postpartum mothers, postpartum visits, hospital 


\section{PENDAHULUAN}

Provinsi Jawa Tengah merupakan salah satu wilayah yang menyumbang Angka Kematian Ibu (AKI) terbesar di Indonesia. Padahal, penurunan AKI menjadi prioritas pertama dalam pembangunan kesehatan 2015 - 2019. Utara, Banten, Jawa Barat, Jawa Tengah, Jawa Timur dan Sulawesi Selatan. Oleh karena itu, penelitian tentang kematian ibu difokuskan di provinsi-provinsi tersebut (Kementrian Kesehatan Republik Indonesia, 2015).

Proporsi kasus kematian ibu di Jawa Tengah terbanyak terjadi pada masa nifas (60,91\%) berdasarkan data Dinas Kesehatan Provinsi Jawa Tengah (2016). Padahal cakupan pelayanan nifas di Jawa Tengah selalu di atas 90\% dan melebihi target nasional. Data tersebut juga menunjukkan bahwa penyebab kematian ibu di Jawa Tengah didominasi perdarahan $(21,14 \%)$ dan pre-eklampsia/eklampsia $(26,34 \%)$.

Sebanyak $85,71 \%$ kematian ibu di Jawa Tengah justru terjadi di rumah sakit. Dugaan faktor determinan kematian ibu di rumah sakit adalah kurangnya informasi yang diperoleh selama hamil, kurangnya tenaga medis, dan rendahnya kualitas pelayanan rumah sakit (Dini, 2017). Faktor-faktor determinan kematian ibu di rumah sakit tersebut masih sebatas dugaan dan perlu pembuktian. Sayangnya, penelitian tentang kematian ibu nifas di rumah sakit di Jawa Tengah belum dilakukan.

Diantara kabupaten/kota di Jawa Tengah, Kota Semarang memiliki cakupan kunjungan nifas terendah se-Jawa Tengah $(86,9 \%)$ dan mempuyai jumlah rumah sakit terbanyak tetapi angka kematiannya termasuk tertinggi (32 kasus tahun 2016). Salah satu dugaan penyebab kematian ibu adalah kurangnya informasi sedangkan di Rumah Sakit Islam Sultan Agung Semarang setiap ibu nifas diberi buku tuntunan tentang masa nifas. Oleh karena itu, tujuan penelitian ini adalah mengetahui pengetahuan tentang kunjungan nifas di Rumah Sakit Islam Sutan Agung Semarang

\section{METODE PENELITIAN}

Jenis penelitian ini adalah explanatory research. Responden penelitian ini adalah ibu nifas yang dirawat inap sebanyak 30 orang. Instrumen penelitian ini berupa kuesioner tentang kunjungan nifas berjumlah 20 pertanyaan yang diuji validitas dengan judgement expert. Tehnik sampling menggunakan metode total sampling. Pengambilan data dilakukan dengan cara survey. Pengolahan data dilakukan dengan nilai minimum, nilai maksimum, rerata dan distribusi frekuensi.

\section{HASIL DAN PEMBAHASAN}

Hasil penelitian ini menunjukkan bahwa skor pengetahuan responden tentang kunjungan nifas yang paling rendah adalah 2, skor yang paling tinggi adalah 10 dan rata-rata skor adalah 5,33. Oleh karena itu, pengetahuan responden tentang kunjungan nifas dikategorikan baik apabila skor 6 atau lebih dan dikategorikan kurang baik apabila skor kurang dari 6 . 


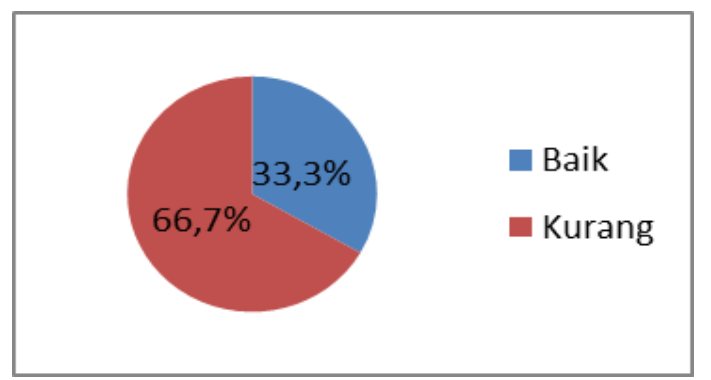

Bagan 4.1 Distribusi Frekuensi Responden Berdasarkan Pengetahuan tentang Kunjungan Nifas

Bagan 4.1 menunjukkan bahwa sebagian besar responden mempunyai pengetahuan tentang kunjungan nifas dalam kategori kurang $(66,7 \%)$. Hal ini ternyata juga terjadi pada ibu nifas di RSUD Pandan Arang Boyolali, Jawa Tengah, bahwa hanya $10 \%$ ibu nifas yang mempunyai pengetahuan baik tentang kunjungan nifas (Marjati, 2013). Demikian pula di Sumatra Utara, hanya 14,7\% ibu nifas yang mempunyai pengetahuan baik tentang pelaksanaan kunjungan nifas (Widianti, 2013). Oleh karena itu, perlu adanya pengembangan media promosi kesehatan reproduksi khusus tentang masa nifas.

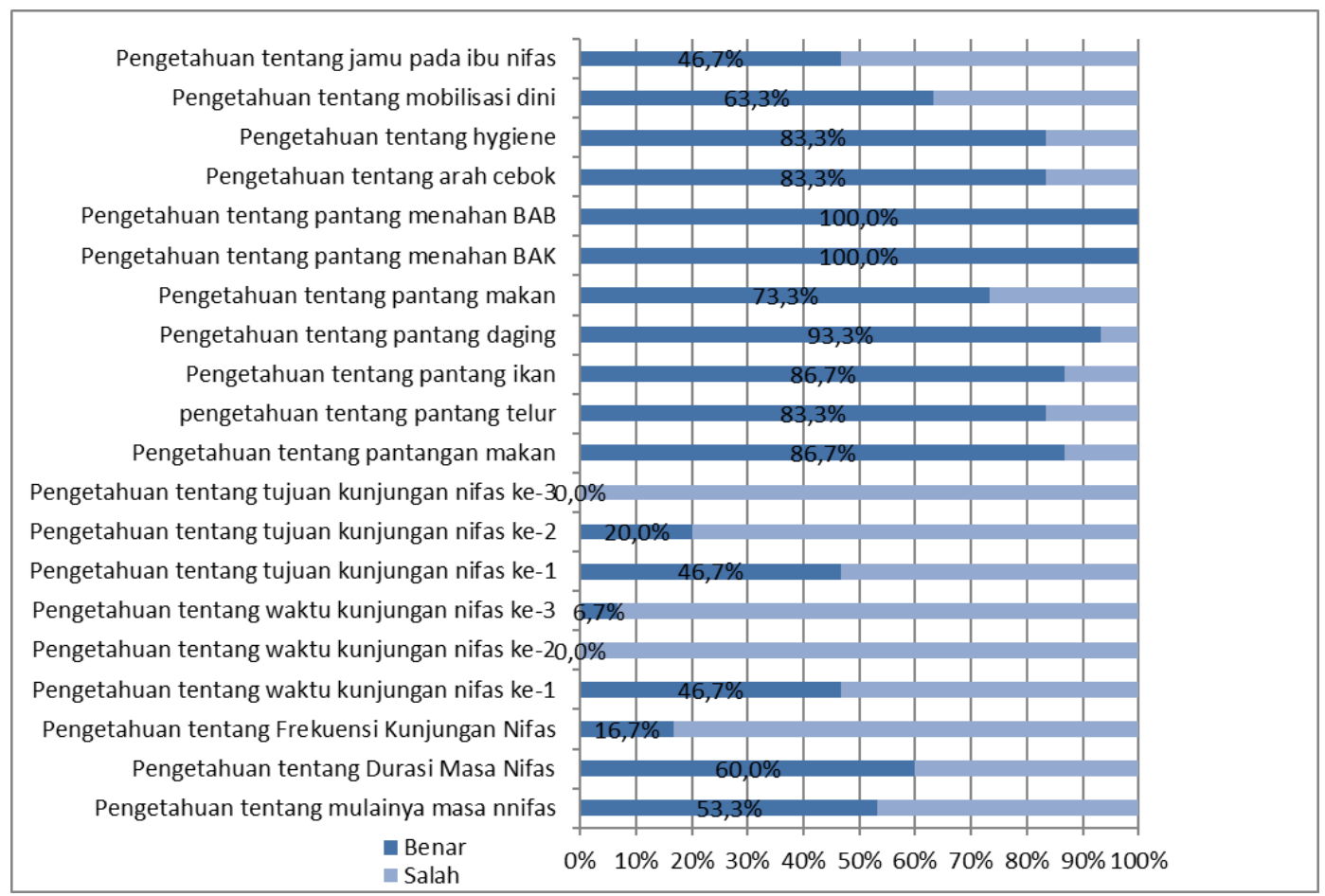

Bagan 4.2. Distribusi Frekuensi Responden Berdasarkan Indikator Pengetahuan tentang Kunjungan Nifas

Bagan 4.2 menunjukkan bahwa indicator pengetahuan yang tidak diketahui responden sama sekali adalah tentang waktu kunjungan nifas kedua $(0 \%)$ dan tujuan kunjungan nifas ketiga (0\%). Selain itu, indikator pengetahuan yang masih kurang dipahami responden adalah tentang waktu kunjungan nifas ketiga $(6,7 \%)$, frekuensi kunjungan nifas (16.7\%), tujuan kunjungan nifas kedua $(20 \%)$, waktu 
kunjungan nifas kesatu (46,7\%), tujuan kunjungan nifas kesatu $(46,7 \%)$ dan tentang jamu (46,7\%). Indikator-indikator pengetahuan tersebut perlu ditekankan kepada ibu nifas dalam media promosi kesehatan reproduksi untuk meningkatkanSebagian besar indicator pengetahuan responden tentang kunjungan nifas yang masih kurang dipahami adalah tentang frekuensi kunjungan dan waktu kunjungan. Kunjungan nifas kedua yang seharusnya dilakukan 6-14 hari pascapersalinan untuk deteksi dini tanda-tanda perdarahan sekunder serta infeksi, ternyata belum banyak diketahui responden. Selain deteksi dini perdarahan dan infeksi, kekambuhan pre-eklampsia juga sering terjadi pada waktu ini karena tubuh sedang melakukan proses withdrawal untuk mengembalikan sistem peredaran darah seperti sediakala (Prawirohardjo, 2010). Tujuan kunjungan nifas ketiga yang terpenting adalah pelayanan kontrasepsi sedini mungkin pada ibu nifas (Saifuddin, 2009).

Hal ini dilakukan untuk mencegah terjadinya kehamilan risiko tinggi akibat jarak kehamilan yang terlalu dekat. Apabila ibu nifas tidak mendapat pelayanan kontrasepsi sedini mungkin, kasus unmet need kontrasepsi akan banyak terjadi. Pengetahuan ibu nifas tentang jamu juga masih rendah (46,7\%). Meskipun jamu merupakan salah satu warisan budaya asli Indonesia, pemanfaatan jamu selama masa nifas perlu diperhatikan supaya tidak mengganggu proses pemulihan masa nifas.

\section{KESIMPULAN}

Sebagian besar responden mempunyai pengetahuan tentang kunjungan nifas dalam kategori kurang. Indikator pengetahuan yang perlu ditekankan pada ibu nifas adalah tentang waktu kunjungan nifas dan tujuan kunjungan nifas KF1 KF3.

\section{DAFTAR PUSTAKA}

Buwono, B. (2015). Memprihatinkan, Angka Kematian Ibu di Kota Semarang Tinggi. Harian Tribun Jateng edisi 19 Agustus 2015.

Cahya, N.P; Dewi, A.P.S. (2017). Efektivitas Vulva Hygiene dengan Air Rebusan Daun Sirih untuk Mempercepat Penyembuhan Luka Perineum pada Ibu Nifas di BPM Heni Winarti, Desa Jatijajar, Kebumen. Karya Tulis Ilmiah D-III Kebidanan STIKES Muhammadiyah Gombong.

Dinas Kesehatan Provinsi Jawa Tengah. (2015). Profil Kesehatan Provinsi Jawa Tengah2015.http://dinkesjatengprov.go.id/v2015/dokumen/profil2015/Profi 1_2015_fix.pdf. Diakses 25 April 2017.

Dini, (2016). Gawat, Baru Lima Bulan Sudah 251 Ibu di Jateng Meninggal karena Kehamilan dan Persalinan. Diakses 2 Mei 2017.

Ikhtiarinawati, F., Dwi, L. (2012). Perbedaan Penurunan TFU Berdasarkan Jenis Persalinan pada Ibu Nifas Fisiologis dan Psot Sectio Caesarea. http://journal.unisla.ac.id/pdf/19512013/3.\%20perbedaan\%20penurunan\% 20tinggi\%20fundus\%20uteri.pdf Diakses 28 Juli 2018.

Kementrian Kesehatan Republik Indonesia. (2016). Profil Kesehatan Indonesia 2015. Jakarta. 
Marjati, D. (2013). Tingkat Pengetahuan Ibu Nifas tentang Kunjungan Masa Nifas di RSUD Pandan Arang Boyolali. Karya Tulis Ilmiah D-III Kebidanan STIKES Kusuma Husada Surakarta. http://digilib.stikeskusumahusada.ac.id/files/disk1/7/01-gdl-destimarja-3251-ktidest-i.pdf . Diakses September 2018.

Notoatmodjo, S. (2010). Pengantar Pendidikan dan Ilmu Perilaku. Jakarta: Rineka Cipta. . (2007). Metode Penelitian. Jakarta: Rineka Cipta.

Prawirohardjo, S. (2010). Ilmu Kebidanan. Jakarta: Yayasan Bina Pustaka Sarwono Prawirohardjo.

Saifuddin, A.B. (2009). Buku Panduan Praktis Pelayanan Kesehatan Maternal dan Neonatal. Jakarta: Yayasan Bina Pustaka - Sarwono Prawirohardjo.

Widianti, Y. (2013). Pengetahua dan Sikap Ibu Nifas terhadap Pelaksanaan Kunjungan Masa Nifas pada PAsien Rumah Bersalin Delima Medan. Karya Tulis Ilmiah D-IV Bidan Pendidik, Fakultas Keperawatan, Universitas Sumatra Utara. Diakses September 2018 